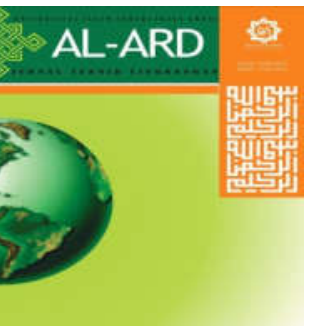

AL-ARD: JURNAL TEKNIK LINGKUNGAN

Vol.4 No.1 - September 2018(21-30)

AL-ARD

JURNAL

TEKNIK LINGKUNGAN

www.al-ard.uinsby.ac.id

\title{
AIR QUALITY SETTLEMENT ASSESSMENT NEAR LOCAL COMMUNITY HEALTH CENTERS (LCHC) IN CIMAHI CITY, WEST JAVA PROVINCE
}

\author{
Ida Munfarida 1 \\ ${ }^{1}$ Environmental Engineering, Facuty of Science and Technology, UIN Sunan Ampel Surabaya, Surabaya \\ munfarida@uinsby.ac.id
}

\begin{abstract}
The Settlements near the Local Community Health Centers (LCHC) may have a negative impact on the settlement environment, especially is air quality due to the transportation sector near LCHC and community activities around the LCHC. This study evaluated air quality in three Settlements near the LCHC in Cimahi City, West Java Province, among others were: settlements in Cimahi Selatan, Cimahi Tengah and Cimahi Utara Districts. The air quality parameters were Nitrogen Dioxide $\left(\mathrm{NO}_{2}\right)$, Sulfur Dioxide $\left(\mathrm{SO}_{2}\right)$, Carbon Monoxide (CO), Ozone $\left(\mathrm{O}_{3}\right)$, and Total Suspended Particulate (TSP) at three Locations of the Settlement. Air Quality Evaluation results indicate that all gaseous parameters were below air quality standards based on Government Law No.41 Year 1999 about Air Pollution Control, but Total Suspended Particulate (TSP) concentration in settlements of Cimahi Tengah and Cimahi Selatan Districts have exceeded the standard. However the lowest gaseous concentration was found in Settlement of Cimahi Tengah District. The community can play a role in improving the air quality in the settlements by providing green open space.

Keywords: Air Quality, Local Community Health Centers (LCHC), Settlement
\end{abstract}

\begin{abstract}
Abstrak
Pemukiman dekat Pusat Kesehatan Masyarakat Lokal (Puskesmas) memiliki dampak negatif pada lingkungan pemukiman, terutama kualitas udara diakibatkan sektor transportasi dekat Puskesmas dan kegiatan masyarakat di sekitar Puskesmas. Studi ini mengevaluasi kualitas udara di tiga Permukiman dekat Puskesmas di Kota Cimahi, Provinsi Jawa Barat, antara lain: Permukiman di Kecamatan Cimahi Selatan, Kecamatan Cimahi Tengah, dan Kecamatan Cimahi Utara. Parameter kualitas udara antara lain Nitrogen Dioksida $\left(\mathrm{NO}_{2}\right)$, Sulfur Dioksida $\left(\mathrm{SO}_{2}\right)$, Karbon Monoksida (CO), Ozon $\left(\mathrm{O}_{3}\right)$, dan Total Partikulat (TSP) di tiga Lokasi Permukiman. Hasil Evaluasi Kualitas Udara menunjukkan bahwa semua parameter gas berada di bawah baku mutu kualitas udara berdasarkan Peraturan Pemerintah No. 41 Tahun 1999 tentang Pengendalian Pencemaran Udara, tetapi Total Partikulat (TSP) di Permukiman Kecamatan Cimahi Tengah dan Cimahi Selatan melebihi baku mutu berdasarkan Peraturan Pemerintah No. 41 Tahun 1999 tentang Pengendalian Pencemaran Udara. Konsentrasi gas ditemukan paling rendah di Permukiman Kecamatan Cimahi Tengah. Masyarakat dapat berperan dalam meningkatkan kualitas udara di permukiman dengan menyediakan ruang terbuka hijau di Permukiman.

Kata Kunci: Kualitas Udara, Permukiman, Puskesmas
\end{abstract}

\section{PENDAHULUAN}

Udara merupakan salah satu media lingkungan yang merupakan kebutuhan dasar manusia sehingga udara yang berkualitas menjadi syarat penting dalam kehidupan (Munfarida, 2016). Adaya pencemar udara di lingkungan atmosfer dapat memberikan dampak negatif terhadap kesehatan manusia. Pencemar udara dapat berupa gas yakni nitrogen oksida ( $\mathrm{NO}, \mathrm{NO}_{2}$ ), sulfur oksida (SO,
$\mathrm{SO}_{2}$ ), karbon monoksida (CO), oksidan $\left(\mathrm{O}_{3}\right)$, Timbal (Pb), gas volatil yang tersebar ke udara dan berupa debu (TSP) atau partikulat (Soedomo, 2001).

Berdasarkan Undang-Undang Nomor 1 Tahun 2011 Tentang Perumahan dan Kawasan Permukiman, Permukiman adalah bagian dari lingkungan hunian yang terdiri atas lebih dari satu satuan perumahan yang mempunyai prasarana, sarana, utilitas umum, 
serta mempunyai penunjang kegiatan fungsi lain di kawasan perkotaan atau kawasan perdesaan. Kawasan permukiman diselenggarakan dengan berasaskan kesejahteraan, keadilan dan pemerataan, kenasionalan, keefisienan dan kemanfaatan, keterjangkauan dan kemudahan, kemandirian dan kebersamaan, kemitraan, keserasian dan keseimbangan, keterpaduan, kesehatan, kelestarian dan keberlanjutan dan keselamatan, keamanan, ketertiban, dan keteraturan (Indonesia, 2011).

Permukiman merupakan salah satu bentuk sarana hunian yang memiliki kaitan yang sangat erat dengan masyarakatnya. Hal ini berarti permukiman di suatu lokasi dapat mencerminkan karakteristik masyarakat yang tinggal di kawasan tersebut. Permukiman dapat diartikan sebagai suatu cerminan dari diri pribadi manusia, baik secara perorangan maupun dalam suatu kesatuan dan kebersamaan dengan lingkungan alamnya dan dapat juga mencerminkan taraf hidup, kesejahteraan, kepribadian, dan peradaban manusia penghuninya, masyarakat ataupun suatu bangsa (Santoso, dkk, 2002).

Penyelenggaraan permukiman adalah pemenuhan kebutuhan perkotaan diwujudkan melalui pembangunan kawasan permukiman skala besar yang terencana secara menyeluruh dan terpadu dengan pelaksanaan yang bertahap sesuai Undang-Undang Nomor 1 Tahun 2011 tentang Perumahan dan Kawasan Permukiman.

Salah satu asas yang melandasi pembangunan di kawasan Permukiman adalah kelestarian yang mengandung makna pembangunan kawasan Permukiman yang berkelanjutan. Pembangunan Berkelanjutan sesuai dengan dua atau tiga dimensi konsep yaitu lingkungan, masyarakat, ekonomi (Eleni Sinakou, dkk , 2018). Studi sebelumnya menyimpulkan bahwa pembangunan berkelanjutan harus secara holistik dimulai dari dalam daripada dari luar sebagai standar komunitas Permukiman (Dayaratne, 2018).

Pembangunan Perumahan dan kawasan permukiman tersebut ditunjukan untuk menciptakan kawasan permukiman dan mengintegrasikan secara terpadu dan meningkatkan kualitas lingkungan, yang dihubungkan oleh jaringan transportasi sesuai dengan kebutuhan dengan kawasan lain yang memberikan berbagai pelayanan dan kesempatan kerja.
Kondisi lingkungan di pemukiman dapat mempengaruhi kondisi sosial ekonomi, kondisi perumahan dan infrastruktur publik (Lisha Tang, dkk 2017). Salah satu kondisi lingkungan yang baik dapat dilihat dari kondisi kualitas udara di Permukiman.

Studi sebelumnya telah menunjukkan dampak negatif dari polusi udara berkorelasi pada tingkat kesejahteraan penduduk di Cina. Polutan Sulfur Dioksida $\left(\mathrm{SO}_{2}\right)$, Nitrogen Dioksida $\left(\mathrm{NO}_{2}\right)$, Partikulat dengan ukuran kurang dari 2,5 $\mu \mathrm{m}\left(\mathrm{PM}_{2,5}\right)$ dan Partikulat dengan ukuran kurang dari $10 \mu \mathrm{m}\left(\mathrm{PM}_{10}\right)$ berdampak negative terhadap kesejahteraan di Permukiman Beijing (Guodong Du, dkk, 2018). Polusi udara telah terbukti memberikan dampak negatif terhadap kesehatan manusia diantaranya timbulnya penyakit yang berkaitan dengan pernafasan dan jantung (Sanyi Tang, dkk, 2018) dan kematian (Jing Huang, dkk, 2018).

Kualitas udara di Permukiman dapat dipengaruhi oleh aktivitas atau kegiatan di sekitar Permukiman terutama di Permukiman perdesaan/perkotaan. Kegiatan di sekitar dapat turut memberikan dampak terhadap kualitas udara di Permukiman, salah satunya adalah adanya Puskesmas dapat berkontribusi terhadap kualitas udara di Permukiman.

Berdasarkan Cimahi Dalam Angka (2017), total jumlah penduduk sebanyak 586.580 jiwa dengan jumlah penduduk tertinggi di Kecamatan Cimahi Selatan sebanyak 254.365 jiwa, kemudian Kecamatan Cimahi Tengah dengan Jumlah 170.916 Jiwa dan jumlah penduduk terendah yaitu di Kecamatan Cimahi Utara sebanyak 161.299 Jiwa. Sementara jumlah Puskesmas di Kota Cimahi sebanyak 17 Puskesmas terdiri dari 13 Puskesmas Umum dan 4 Puskesmas Pembantu yang tersebar di 3 Kecamatan (Statistik, 2017). Berdasarkan data pasien, terjadi peningkatan pasien dari tahun 2012 hingga 2015 (Statistik, 2017).

Puskesmas di Kota Cimahi pada umumnya berada tidak jauh dari Permukiman Penduduk. Adanya kegiatan kunjungan ke Puskesmas menyebabkan meningkatnya arus lalu lintas menuju lokasi yang dapat memberikan dampak terhadap kualitas udara di Permukiman sekitar Puskesmas. Penelitian ini bertujuan untuk mengetahui kualitas udara Permukiman dekat lokasi Puskesmas dalam rangka pengelolaan dan monitoring kualitas udara Permukiman. Kualitas udara yang baik 
di Permukiman diharapkan dapat meningkatkan kesejahteraan masyarakat.

Monitoring kualitas udara Permukiman diselenggarakan dalam rangka mendukung pembangunan Permukiman berkelanjutan berdasarkan rencana tata ruang wilayah yang berfungsi sebagai lingkungan hunian dan tempat kegiatan yang mendukung perikehidupan dan penghidupan yang terencana, menyeluruh, terpadu, dan berkelanjutan. Kualitas udara yang baik di Permukiman diharapkan meningkatkan kesehatan masyarakat sehingga berkorelasi positif dengan kemampuan bekerja dan pada akhirnya meningkatkan pendapatan masyarakat sebagai indikator peningkatan kesejahteraan masyarakat. Dengan mengetahui tingkat kualitas udara di kawasan Permukiman, dengan demikian masyarakat dapat berperan aktif meningkatkan kualitas udara melalui pemberdayaan masyarakat di kawasan Permukiman dan turut serta dalam program Pemerintah Kota dalam meningkatkan kualitas lingkungan khususnya di Kota Cimahi Provinsi Jawa Barat.

\section{METODE PENELITIAN}

Metodelogi yang digunakan dalam pelaksanaan penelitian ini adalah pengukuran kualitas udara langsung di lokasi penelitan bekerja sama dengan PDAM Tirta Wening Kota Bandung. Teknik sampling menggunakan metode purposive sampling dan sampling sesaat untuk mengetahui kondisi kualitas udara eksisting di Permukiman dekat lokasi Puskesmas yang mewakili di tiga Kecamatan di Kota Cimahi. Lokasi Permukiman meliputi tiga lokasi Permukiman dekat Puskesmas di Kecamatan Cimahi Tengah, Kecamatan Cimahi Selatan, Cimahi, Kecamatan Cimahi Utara.

Kualitas udara yang disampling adalah kualitas udara ambient. Sampling kualitas udara ambien adalah sampling kualitas udara pada media penerima polutan udara/emisi udara.

Tujuan sampling udara ambien adalah: (a) untuk mengetahui tingkat pencemaran udara yang ada di suatu daerah, dengan mengacukannya kepada ketentuan dan peraturan mengenai kualitas udara yang berlaku dan baku mutu udara yang berlaku; (b) Untuk menyediakan pengumpulan data (data base) yang diperlukan dalam evaluasi pengaruh pencemaran dan pertimbangan perancangan, seperti: pengembangan kota dan tata guna lahan, transportasi, evaluasi penerapan strategi pengendalian pencemaran yang telah dilakukan; validasi pengembangan model dilusi dan dispersi pencemaran udara yang ada; evaluasi dan peramalan tingkattingkat pencemaran episodik, jangka panjang dan jangka pendek; (c) Untuk mengamati kecenderungan tingkat pencemaran yang ada di daerah pengendalian pencemaran udara tertentu, termasuk daerah perkotaan dan (d) Untuk mengaktifkan dan menentukan prosedur pengendalian darurat guna mencegah timbulnya episoda pencemaran udara (Soedomo, 2001). Teknik sampling udara ambient terdiri dari sampling terus menerus (kontinu), sampling setengah kontinu dan sampling sesaat tidak kontinu (Soedomo, 2001). Dalam penelitian ini dilakukan sampling sesaat tidak kontinu adalah pengukuran satu atau dua kali yang tidak kontinyu dan tidak secara periodic atau hanya dilakukan pada saat-saat tertentu saja.

Parameter kualitas udara yang diukur meliputi gas dan partikulat antara lain nitrogen dioksida $\left(\mathrm{NO}_{2}\right)$, sulfur dioksida $\left(\mathrm{SO}_{2}\right)$, karbon monoksida (CO), oksidan $\left(\mathrm{O}_{3}\right)$, dan partikulat (TSP). Pengukuran dilakukan pada waktu siang hari sebanyak satu kali pengukuran. Pengukuran dilakukan selama 1 jam.

Pengukuran nitrogen dioksida $\left(\mathrm{NO}_{2}\right)$, sulfur dioksida $\left(\mathrm{SO}_{2}\right)$, oksidan $\left(\mathrm{O}_{3}\right)$, dan partikulat (TSP) menggunakan peralatan tabung dan impinger, sementara untuk karbon monoksida (CO) menggunakan CO Analyzer dengan metode direct reading. Prinsip peralatan impinger yaitu absorpsi. Teknik absorpsi adalah teknik pengumpulan gas berdasarkan kemampuan gas pencemar terabsorpsi atau bereaksi dengan larutan pereaksi spesifik (larutan absorben). Pereaksi kimia yang digunakan harus spesifik artinya hanya dapat bereaksi dengan gas pencemar tertentu yang akan di analisis (Soedomo, 2001).

Hasil pengukuran kualitas udara kemudian dianalisis secara deskriptif dengan membandingkan dengan Baku Mutu Udara Ambient mengacu pada Peraturan Pemerintah No. 41 Tahun 1999 Tentang Pengendalian Pencemaran Udara. Berikut adalah diagram alir penelitian: 


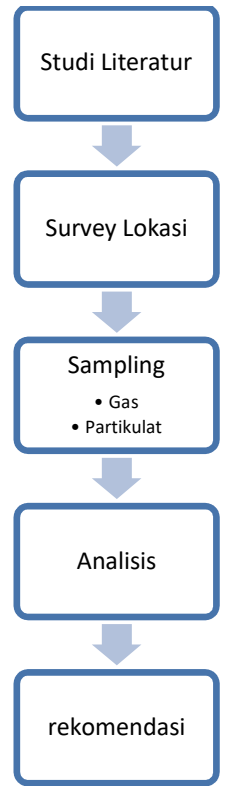

Gambar 1. Diagram Alir Penelitian

\section{HASIL DAN PEMBAHASAN}

Kota Cimahi secara geografis terletak diantara 1070 30'30" - 1070 34'30' BT dan 60 50 ' 00' - 60 56'00' Lintang Selatan. Kota Cimahi termasuk ke dalam wilayah Propinsi Jawa Barat dan meliputi 3 Kecamatan yang terdiri dari 15 Kelurahan, yaitu: Kecamatan Cimahi Utara terdiri dari 4 Kelurahan, Kecamatan Cimahi Tengah terdiri dari 6 Kelurahan dan Kecamatan Cimahi Selatan terdiri dari 5 Kelurahan. Secara geografis wilayah ini merupakan lembah cekungan yang melandai ke arah selatan, dengan ketinggian di bagian utara $\pm 1,040$ meter dpl (Kelurahan Cipageran Kecamatan Cimahi Utara), yang merupakan lereng Gunung Burangrang dan Gunung Tangkuban Perahu serta ketinggian di bagian selatan sekitar \pm 685 meter dpl (Kelurahan Melong Kecamatan Cimahi Selatan) yang mengarah ke Sungai Citarum (Statistik, 2017).

Wilayah Kota Cimahi memiliki luas 40,2 $\mathrm{km}^{2}$ yang tersebar di tiga kecamatan yaitu kecamatan Cimahi Selatan, Cimahi Utara dan Cimahi Tengah. Diantara ketiga kecamatan tersebut Cimahi Selatan merupakan daerah terluas yaitu seluas 16,9 $\mathrm{km}^{2}$ dengan penduduk sebanyak 254.365 jiwa, dan yang luasnya terkecil adalah Cimahi Tengah yaitu seluas $10,0 \mathrm{~km}^{2}$ dengan jumlah penduduk sebanyak 170.916 jiwa. Secara keseluruhan pada tahun 2016 Kota Cimahi memiliki penduduk sebanyak 586.580 jiwa. Tingkat kepadatan Kota Cimahi tahun 2016 adalah 14.592 jiwa/ $\mathrm{km}^{2}$, dimana kecamatan Cimahi Tengah memiliki kepadatan penduduk tertinggi dibandingkan dua kecamatan lainnya yaitu mencapai 17.092 jiwa $/ \mathrm{km}^{2}$. Hal ini terjadi disebabkan oleh mobilitas penduduk yang cukup tinggi karena penduduk lebih terkonsentrasi di pusat perkotaan Cimahi dengan keanekaragamannya (Statistik, 2017).

Permukiman yang dilakukan montirong udara merupakan Permukiman dengan padat penduduk di Kecamatan Cimahi Selatan, Cimahi Utara dan Cimahi Tengah dekat dengan Puskesmas pavorit di kawasan tersebut.

Di Kecamatan Cimahi Tengah, sampling dilakukan di koordinat S 0653'15,7' \& E 107º 32' 52,0" tepatnya di Kelurahan Cigugur Tengah. Dengan karakteristik kondisi lingkungan sebagai berikut:

Tabel 1. Kondisi Lingkungan Permukiman di Kecamatan Cimahi Tengah

\begin{tabular}{lll}
\hline Parameter & Nilai & Satuan \\
\hline Suhu & 31,43 & ${ }^{\circ} \mathrm{C}$ \\
\hline Kecepatan Angin & 0,6 & $\mathrm{~m} /$ det \\
\hline Kelembaban & 58,23 & $\%$ \\
\hline Tekanan & 696,45 & $\mathrm{mmHg}$ \\
\hline Arah Angin Dominan & Timur & - \\
\hline $\begin{array}{l}\text { (Sumber: Laboratorium } \\
\text { Bandung, 2014) }\end{array}$ & PDAM Tirta & Wening Kota
\end{tabular}

Temperatur pada saat pengukuran adalah $31.43^{\circ} \mathrm{C}$. Arah angin dominan ke Timur dengan kecepatan $0.6 \mathrm{~m} /$ detik. Kelembaban udara sebesar 58,23 \% dan tekanan udara sebesar $696,45 \mathrm{mmHg}$.

Tabel 2 adalah hasil sampling kualitas udara di Permukiman di Kecamatan Cimahi Tengah.

Tabel 2. Kualias Udara Permukiman di Kecamatan Cimahi Tengah.

\begin{tabular}{clccc}
\hline No & Parameter & Satuan & $\begin{array}{c}\text { Baku } \\
\text { Mutu }\end{array}$ & $\begin{array}{c}\text { Hasil } \\
\text { Pengujian }\end{array}$ \\
\hline 1 & $\begin{array}{l}\text { Nitrogen } \\
\text { Dioksida } \\
\left(\mathrm{NO}_{2}\right)\end{array}$ & $\mu \mathrm{g} / \mathrm{Nm}^{3}$ & 400 & 12.56 \\
\hline 2 & $\begin{array}{l}\text { Sulfur } \\
\text { Dioksida } \\
\text { (SO })\end{array}$ & $\mu \mathrm{g} / \mathrm{Nm}^{3}$ & 900 & 18.23 \\
\hline 3 & $\begin{array}{l}\text { Karbon } \\
\text { Monoksida } \\
\text { (CO) }\end{array}$ & $\mu \mathrm{g} / \mathrm{Nm}^{3}$ & 30.000 & $<1.145$ \\
\hline 4 & Oksidan $\left(\mathrm{O}_{3}\right)$ & $\mu \mathrm{g} / \mathrm{Nm}^{3}$ & 235 & $<15,61$ \\
\hline 5 & Debu $(\mathrm{TSP})$ & $\mu \mathrm{g} / \mathrm{Nm}^{3}$ & 230 & 261 \\
\hline
\end{tabular}

(Sumber: Laboratorium PDAM Tirta Wening Kota Bandung, 2014) 
Berdasarkan hasil analisis laboratorium untuk kualitas udara di Kecamatan Cimahi Tengah, kualitas udara yakni parameter gas masih memenuhi baku mutu, hal ini terlihat dari nilai hasil uji untuk Nitrogen Dioksida $\left(\mathrm{NO}_{2}\right)$ adalah $12,56 \mu \mathrm{g} / \mathrm{Nm}^{3}$ sementara baku mutu adalah $400 \mu \mathrm{g} / \mathrm{Nm}^{3}$, nilai uji Sulfur Dioksida $\left(\mathrm{SO}_{2}\right)$ diperoleh $18.23 \mu \mathrm{g} / \mathrm{Nm}^{3}$ (baku mutu $\mathrm{SO}_{2}=900 \mu \mathrm{g} / \mathrm{Nm}^{3}$ ), nilai uji Karbon Monoksida (CO) diperoleh $<1.145 \mu \mathrm{g} / \mathrm{Nm}^{3}$ (baku mutu $\mathrm{CO}=30.000 \mu \mathrm{g} / \mathrm{Nm}^{3}$ ), nilai uji Oksidan $\left(\mathrm{O}_{3}\right)$ diperoleh $<15,61 \mu \mathrm{g} / \mathrm{Nm}^{3}$ (baku mutu $=235 \mu \mathrm{g} / \mathrm{Nm}^{3}$ ), sementara partikulat (TSP) diperoleh hasil $261 \mu \mathrm{g} / \mathrm{Nm}^{3}$ (baku mutu $\mathrm{TSP}=230 \mu \mathrm{g} / \mathrm{Nm}^{3}$ ) sehingga nilai partikulat (TSP) diketahui melebihi baku mutu.

Di Kecamatan Cimahi Selatan, sampling dilakukan di koordinat S 06 ${ }^{\circ} 55^{\prime} 24,3^{\prime \prime}$ \& E $107^{\circ}$ 33'47,1" tepatnya di Kelurahan Melong. Dengan karakteristik kondisi lingkungan sebagai berikut:

Tabel 3. Kondisi Lingkungan Permukiman di Kecamatan Cimahi Selatan

\begin{tabular}{|c|c|c|}
\hline Parameter & Nilai & Satuan \\
\hline Suhu & 29,13 & ${ }^{\circ} \mathrm{C}$ \\
\hline Kecepatan Angin & 0,3 & $\mathrm{~m} / \mathrm{det}$ \\
\hline Kelembaban & 63,15 & $\%$ \\
\hline Tekanan & 700,73 & $\mathrm{mmHg}$ \\
\hline Arah Angin Dominan & Timur & - \\
\hline
\end{tabular}

Temperatur pada saat pengukuran adalah $29,13^{\circ} \mathrm{C}$. Arah angin dominan ke Timur dengan kecepatan $0.3 \mathrm{~m} /$ detik. Kelembaban udara sebesar 63,15\% dan tekanan udara sebesar $700,73 \mathrm{mmHg}$.

Tabel 4 adalah hasil sampling kualitas udara di Permukiman di Kecamatan Cimahi Selatan.

Tabel 4. Kualias Udara Permukiman di Kecamatan Cimahi Selatan

\begin{tabular}{|c|c|c|c|c|}
\hline No & Parameter & Satuan & $\begin{array}{l}\text { Baku } \\
\text { Mutu }\end{array}$ & $\begin{array}{c}\text { Hasil } \\
\text { Pengujian } \\
\text { (Testing } \\
\text { Result) } \\
\end{array}$ \\
\hline 1 & $\begin{array}{l}\text { Nitrogen } \\
\text { Dioksida } \\
\left(\mathrm{NO}_{2}\right)\end{array}$ & $\mu \mathrm{g} / \mathrm{Nm}^{3}$ & 400 & 18,76 \\
\hline 2 & $\begin{array}{l}\text { Sulfur } \\
\text { Dioksida } \\
\left(\mathrm{SO}_{2}\right) \\
\end{array}$ & $\mu \mathrm{g} / \mathrm{Nm}^{3}$ & 900 & 22,09 \\
\hline 3 & $\begin{array}{l}\text { Karbon } \\
\text { Monoksida } \\
(\mathrm{CO})\end{array}$ & $\mu \mathrm{g} / \mathrm{Nm}^{3}$ & 30.000 & $<1.145$ \\
\hline 4 & Oksidan $\left(\mathrm{O}_{3}\right)$ & $\mu \mathrm{g} / \mathrm{Nm}^{3}$ & 235 & 16.89 \\
\hline 5 & Debu (TSP) & $\mu \mathrm{g} / \mathrm{Nm}^{3}$ & 230 & 282 \\
\hline
\end{tabular}

Sementara di Kecamatan Cimahi Utara, sampling dilakukan di koordinat S 06051'39,8" \& E 107० 32'45,3" tepatnya di Kelurahan Citeuteup. Dengan karakteristik kondisi lingkungan sebagai berikut:

Tabel 5. Kondisi Lingkungan Permukiman di Kecamatan Cimahi Utara

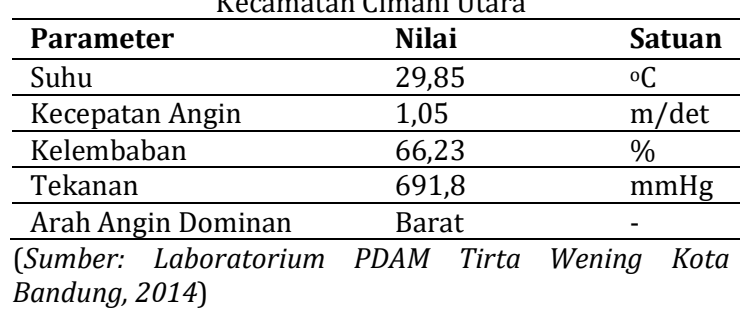

Temperatur pada saat pengukuran adalah $29,85^{\circ} \mathrm{C}$. Arah angin dominan ke Barat dengan kecepatan 1,05 m/detik. Kelembaban udara sebesar $66,23 \%$ dan tekanan udara sebesar $691,8 \mathrm{mmHg}$.

Berikut adalah hasil sampling kualitas udara di Permukiman di Kecamatan Cimahi Utara.

Tabel 6. Kualias Udara Permukiman di Kecamatan Cimahi Utara.

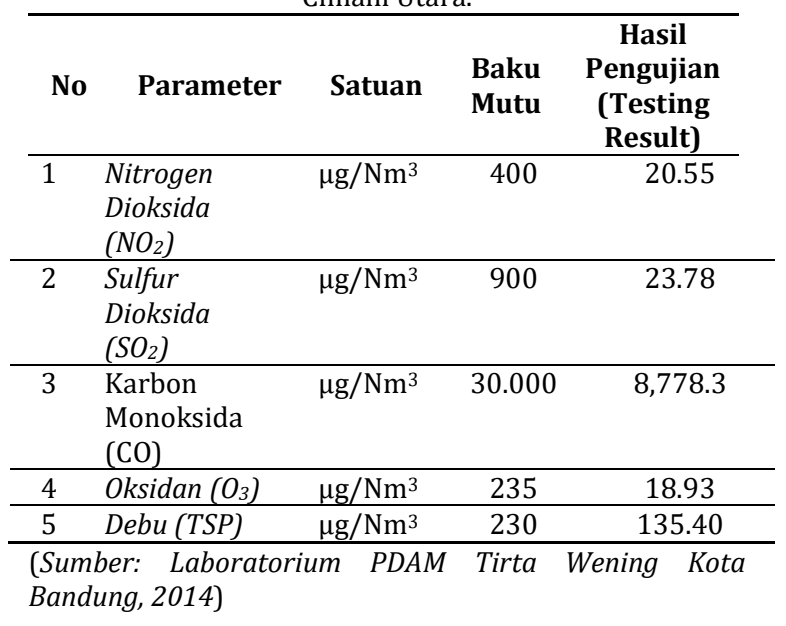

Berdasarkan hasil analisis laboratorium untuk kualitas udara di Permukiman Cimahi Utara, kualitas udaranya masih memenuhi baku mutu baik gas dan partikulat, hal ini terlihat dari nilai hasil uji untuk Nitrogen Dioksida $\quad\left(\mathrm{NO}_{2}\right)$ adalah $20,55 \mu \mathrm{g} / \mathrm{Nm}^{3}$ sementara baku mutu adalah $400 \mu \mathrm{g} / \mathrm{Nm}^{3}$, nilai uji Sulfur Dioksida $\left(\mathrm{SO}_{2}\right)$ diperoleh 23,78 $\mu \mathrm{g} / \mathrm{Nm}^{3}$ (baku mutu $\mathrm{SO}_{2}=900 \mu \mathrm{g} / \mathrm{Nm}^{3}$ ), nilai uji Karbon Monoksida (CO) diperoleh 8.778,3 $\mu \mathrm{g} / \mathrm{Nm}^{3}$ (baku mutu $\mathrm{CO}=30.000 \mu \mathrm{g} / \mathrm{Nm}^{3}$ ), nilai uji Oksidan $\left(\mathrm{O}_{3}\right)$ diperoleh $18,93 \mu \mathrm{g} / \mathrm{Nm}^{3}$ (baku mutu=235 $\mu \mathrm{g} / \mathrm{Nm}^{3}$ ), sementara partikulat (TSP) diperoleh hasil 135,40 $\mu \mathrm{g} / \mathrm{Nm}^{3}$ (baku mutu TSP=230 $\mu \mathrm{g} / \mathrm{Nm}^{3}$ ). 
Jika dibandingkan nilai hasil pengukuran kualitas lingkungan, temperature tertinggi terjadi di lokasi Permukiman Kecamatan Cimahi Tengah, Kecepatan Angin dan kelembaban udara tertinggi terjadi di lokasi Permukiman Kecamatan Cimahi Utara, dan tekanan udara tertinggi terjadi di lokasi Permukiman Kecamatan Cimahi Selatan (Tabel 7).

Jika dibandingkan hasil uji parameter gas dan partikulat dari ketiga lokasi permukiman, maka untuk parameter gas dan partikulat terendah terjadi di lokasi Permukiman Kecamatan Cimahi Tengah.

Tabel 7. Kondisi Lingkungan di 3 lokasi Permukiman di Kota Cimahi

\begin{tabular}{llll}
\hline Parameter & \multicolumn{1}{c}{ I } & \multicolumn{1}{c}{ II } & \multicolumn{1}{c}{ III } \\
\hline Suhu & $31,43^{\circ} \mathrm{C}$ & $29,13^{\circ} \mathrm{C}$ & $29,85{ }^{\circ} \mathrm{C}$ \\
\hline $\begin{array}{l}\text { Kecepatan } \\
\text { Angin }\end{array}$ & $0,6 \mathrm{~m} /$ det & $0,3 \mathrm{~m} /$ det & $\begin{array}{l}1,05 \\
\mathrm{~m} / \text { det }\end{array}$ \\
\hline $\begin{array}{l}\text { Arah Angin } \\
\text { Dominan }\end{array}$ & Timur & Timur & Barat \\
\hline Kelembaban & $58,23 \%$ & $63,15 \%$ & $66,23 \%$ \\
\hline Tekanan & 696,45 & 700,73 & 691,8 \\
& $\mathrm{mmHg}$ & $\mathrm{mmHg}$ & $\mathrm{mmHg}$ \\
\hline
\end{tabular}

\section{Ket:}

I: Lokasi Permukiman Kec. Cimahi Tengah

II: Lokasi Permukiman Kec. Cimahi Selatan

III: Lokasi Permukiman Kec. Cimahi Utara

Tabel 8. Kualias Udara di 3 lokasi Permukiman di Kota Cimahi

\begin{tabular}{|c|c|c|c|c|c|}
\hline \multirow{2}{*}{ No } & \multirow{2}{*}{ Parameter } & \multirow{2}{*}{ Satuan } & \multicolumn{3}{|c|}{ Hasil Pengujian } \\
\hline & & & $\mathrm{I}$ & Ii & Iii \\
\hline 1 & $\begin{array}{l}\text { Nitrogen } \\
\text { Dioksida } \\
\left(\mathrm{NO}_{2}\right) \\
\end{array}$ & $\begin{array}{c}\mu \mathrm{g} / \\
\mathrm{Nm}^{3}\end{array}$ & 12.56 & 18.76 & 20.55 \\
\hline 2 & $\begin{array}{l}\text { Sulfur } \\
\text { Dioksida } \\
\left(\mathrm{SO}_{2}\right)\end{array}$ & $\begin{array}{c}\mu \mathrm{g} / \\
\mathrm{Nm}^{3}\end{array}$ & 18.23 & 22.09 & 23.78 \\
\hline 3 & $\begin{array}{l}\text { Karbon } \\
\text { Monoksida } \\
(\mathrm{CO}) \\
\end{array}$ & $\begin{array}{c}\mu \mathrm{g} / \\
\mathrm{Nm}^{3}\end{array}$ & $<1.145$ & $<1.145$ & $8,778.3$ \\
\hline 4 & $\begin{array}{l}\text { Oksidan } \\
\left(\mathrm{O}_{3}\right)\end{array}$ & $\begin{array}{l}\mu \mathrm{g} / \\
\mathrm{Nm}^{3}\end{array}$ & $<15,61$ & 16.89 & 18.93 \\
\hline 5 & Debu (TSP) & $\begin{array}{l}\mu \mathrm{g} / \\
\mathrm{Nm}^{3}\end{array}$ & 261 & 282 & 135.40 \\
\hline
\end{tabular}

Ket:

I:Lokasi Permukiman Kec. Cimahi Tengah II: Lokasi Permukiman Kec. Cimahi Selatan III: Lokasi Permukiman Kec. Cimahi Utara

Hasil uji laboratorium menunjukkan bahwa semua parameter udara gas yang diuji yakni nitrogen dioksida $\left(\mathrm{NO}_{2}\right)$, sulfur dioksida $\left(\mathrm{SO}_{2}\right)$, karbon monoksida (CO), oksidan $\left(\mathrm{O}_{3}\right)$, pada tiga lokasi permukiman di Kota Cimahi masih memenuhi baku mutu udara ambient berdasarkan Peraturan Pemerintah No. 41
Tahun 1999 tentang pengendalian pencemaran udara. Sementara nilai partikulat untuk lokasi Permukiman di Kecamatan Cimahi Selatan dan Kecamatan Cimahi Utara melebihi baku mutu.

Tidak ada perbedaan signifikan temperature pada tiga lokasi Permukiman, temperature berkisar antara $29-31^{\circ} \mathrm{C}$.

Walaupun pada umumnya terjadi peningkatan polutan ketika terjadi kenaikan temperature dalam kondisi iklim yang panas (Egide Kalisa, dkk, 2018). Namun dispersi polutan di udara juga dipengaruhi oleh kecepatan angin. Penelitian terdahulu membuktikan bahwa kecepatan angin berpengaruh pada terbentuknya formasi partikulat baru di udara, selain itu kecepatan angin berpengaruh terhadap penyisihan partikel dan prekursor gas eksisting. Semakin tinggi kecepatan angin, maka penyisihan prekursor gas dan partikulat akan semakin banyak terjadi, walaupun hal ini tergantung pada keseimbangan antara keduanya (Buddhi Pushpawela, dkk, 2018).

Berdasarkan Soedomo (2001), konsentrasi pencemar udara di atmosfer dipengaruhi oleh faktor difusi. Faktor difusi berhubungan dengan struktur lingkungan udara, sedangkan faktor lainnya berhubungan dengan emisi yang dikeluarkan oleh kegiatan.

Penelitian terdahulu menjelaskan bahwa musim dan kelembaban mempengaruhi polutan gas. Polutan gas meningkat saat musim dingin (Hong Qiu, dkk, 2013). Beberapa faktor berpengaruh terhadap peningkatan pencemar udara, misalnya Produk Domestik Bruto (GDP), dan kendaraan pribadi meningkatkan kadar Partikulat di Kota, termasuk juga konsumsi energi berpengaruh positif terhadap pencemar udara (Danting Zhao, dkk, 2018).

Tingginya kadar Nitrogen Dioksida $\left(\mathrm{NO}_{2}\right)$, Sulfur Dioksida $\left(\mathrm{SO}_{2}\right)$, Karbon Monoksida (CO) dan Oksidan $\left(\mathrm{O}_{3}\right)$ di lokasi Permukiman Kecamatan Cimahi Utara dapat berasal dari pencemar di lokasi kegiatan dan pencemar di sekitar lokasi kegiatan yakni Puskesmas di Kelurahan Citeureup. Nitrogen Dioksida $\left(\mathrm{NO}_{2}\right)$, Sulfur Dioksida $\left(\mathrm{SO}_{2}\right)$, Karbon Monoksida (CO) dapat berasal dari hasil pembakaran kayu dan bahan bakar minyak (Sinha, 2018). NO diemisikan dalam jumlah yang cukup besar ke atmosfer. $\mathrm{NO}_{2}$ diemisikan dari pembuangan pembakaran (kombusi) pada temperatur tinggi, sebagai hasil dari reaksi nitrogen 
dengan oksigen. Industri dan kendaraan bermotor merupakan aktivitas utama yang mengemisikan senyawa $\mathrm{NO}_{2}$. Selain itu, $\mathrm{NO}_{2}$ juga dihasilkan dari aktivitas alam seperti metabolisme bakterial (Soedomo, 2001).

Sulfur Dioksida $\left(\mathrm{SO}_{2}\right)$ merupakan pencemar udara golongan oksida sulfur. Oksida sulfur merupakan pencemar yang paling umum, terutama ditimbulkan akibat pembakaran bahan bakar fosil. Sulfur dioksida merupakan bagian yang paling dominan, sehingga oksida sulfur biasanya diukur sebagai sulfur dioksida. Sementara Karbon Monoksida (CO) merupakan pencemar udara yang paling besar dan umum dijumpai. Sebagian besar CO terbentuk akibat proses pembakaran bahanbahan karbon yang digunakan sebagai bahan bakar, secara tidak sempurna. Semua aktivitas yang melibatkan pembakaran bahan-bahan organik merupakan sumber karbon monoksida. CO juga dapat terbentuk dari proses alami (Soedomo, 2001).

Sehingga pada umumnya, polutan gas merupakan hasil dari sektor transportasi di sekitar lokasi Permukiman di Kecamatan Cimahi Utara. Sementara Ozon $\left(\mathrm{O}_{3}\right)$ merupakan pencemar udara golongan oksidan. Ozon merupakan senyawa yang paling dominan. Oksida fotokimia dapat ditemui disetiap tempat dimana terdapat oksida nitrogen dan hydrogen yang berinteraksi di bawah radiasi sinar matahari (Soedomo, 2001).

Konsentrasi ozon biasanya berhubungan dengan ketinggian wilayah. Hal ini berhubungan dengan reaksi fotokimia sebagai influx dari troposfer. Penelitian sebelumnya melaporkan bahwa terjadi peningkatan ozon pada wilayah yang lebih tinggi elevasinya di bagian utara Pegunungan Alpen Timur yang meningkat lebih dari dua kali lipat dibandingkan di dataran rendah sejak tahun 1950-an (H. Puxbaum, dkk, 1991).

Dengan demikian, jika melihat ketinggian wilayah, berikut adalah data ketinggian wilayah di Kota Cimahi:

Tabel 8. Ketinggian Wilayah Kota Cimahi berdasarkan Kecamatan

\begin{tabular}{ccc}
\hline No & Kecamatan & Ketinggian (mdpl) \\
\hline 1 & Cimahi Selatan & 700 \\
\hline 2 & Cimahi Tengah & 700 \\
\hline 3 & Cimahi Utara & 735 \\
\hline (sumber: Statistik, 2017) &
\end{tabular}

Berdasarkan ketinggian wilayah, Kecamatan Cimahi Utara berada pada ketinggian 735 mdpl tertinggi diantara 2 Kecamatan lainnya di Kota Cimahi. Hal ini dapat memberikan penjelasan bahwa ketinggian wilayah mungkin menyebabkan pula konsentrasi ozon dan pencemar gas lainnya lebih tinggi dibandingkan dengan 2 Kecamatan lainnya disamping faktor-faktor dilusi pencemar gas lainnya.

Sementara Partikulat yang diukur dalam penelitian ini adalah TSP (Total Suspended Particulate). TSP terdiri atas partikulat padat dan cair yang berukuran dari 100 mikron hingga kurang dari 0,01 mikron (Soedomo, 2001). Kandungan konsentasi yang terukur dari penelitian adalah gabungan dari semua jenis partikel, padat dan cair. Hampir semua jenis aktivitas manusia akan mengeluarkan emisi partikulat ke udara ambien.

Tidak seperti pencemar gas, partikulat atau total suspended particulate (TSP) berkorelasi negatif dengan ketinggian wilayah. Penelitian terdahulu menyebutkan bahwa konsentrasi $\mathrm{PM}_{2.5}$ dan $\mathrm{PM}_{10}$ menurun secara dramatis dengan meningkatnya ketinggian yang ditunjukkan oleh hubungan nonlinier antara konsentrasi partikulat (PM) dan ketinggian. Hubungan ini divalidasi oleh profil koefisien kepunahan dari observasi CALIPSO dan data EV-lidar, sehingga digunakan untuk mencerminkan distribusi vertikal konsentrasi PM di udara (Guicai Ning, dkk, 2018). Dengan demikian, hal ini sama terjadi pada konsentrasi TSP yang terendah terjadi di Permukiman Kecamatan Cimahi Utara yang memiliki ketinggian tertinggi diantara dua Kecamatan lainnya. Sehingga ketinggian wilayah dapat mempengaruhi konsentrasi pencemar di udara.

Fenomena pencemar udara di permukaan dan atmosfer dapat dijelaskan bahwa kondisi atmosfer vertikal memiliki efek yang kuat pada pencampuran vertikal polutan udara, yang secara langsung mempengaruhi kualitas udara permukaan. Hasil penelitian sebelumnya menunjukkan bahwa konsentrasi polutan yang relatif tinggi terjadi di bawah gradien temperatur troposfer pada tingkat menengah yang relatif rendah, kelembaban relatif rendah, angin selatan yang lemah (atau angin utara yang kuat) dan angin barat yang lemah (atau angin timur yang kuat). Selain itu, korelasi bervariasi di antara jenis polutan, musim, dan variabel meteorologi di berbagai ketinggian. Secara umum, sensitivitas polutan terhadap variabel meteorologi ditemukan lebih besar di musim dingin daripada di 
musim lain, dan sensitivitas ozon terhadap meteorologi berbeda dari kedua polutan lainnya. Selain itu, ditemukan bahwa variabel meteorologi hingga pertengahan troposfer $(\sim 700 \mathrm{mb})$ memainkan peran penting dalam mempengaruhi kualitas udara permukaan, menentukan hubungan yang signifikan dan unik antara variabel meteorologi di ketinggian yang lebih tinggi dan kualitas udara permukaan (Cheuk Hei Marcus Tong, dkk, 2018).

Berdasarkan hasil penelitian, didapatkan bahwa semua parameter udara gas yang diuji yakni nitrogen dioksida $\left(\mathrm{NO}_{2}\right)$, sulfur dioksida $\left(\mathrm{SO}_{2}\right)$, karbon monoksida ( $\left.\mathrm{CO}\right)$, oksidan $\left(\mathrm{O}_{3}\right)$, pada tiga lokasi permukiman di Kota Cimahi masih memenuhi baku mutu udara ambient berdasarkan Peraturan Pemerintah No. 41 Tahun 1999 tentang pengendalian pencemaran udara. Sementara nilai partikulat untuk lokasi Permukiman di Kecamatan Cimahi Selatan dan Kecamatan Cimahi Utara melebihi baku mutu.

Salah satu upaya untuk meningkatkan kualitas udara di Permukiman adalah ketersediaan ruang terbuka hijau. Telah banyak para ahli membuktikan bahwa ruang terbuka hijau signifkan dalam mereduksi berbagai polutan gas dan partikulat. Misalnya penelitian di Kota Strasbourg menghasilkan bahwa ketersediaan pohon publik di Kota Strasbourg mengurangi sekitar $7 \%$ dari emisi $\mathrm{PM}_{10}$ yang diemisikan di atmosfer kota; Namun, efek pada polutan udara lainnya kecil. Namun demikian, penelitian ini mengungkapkan bahwa pohon perkotaan merupakan elemen penting untuk mengurangi polusi udara walaupun bukan satu-satunya solusi untuk masalah ini. Saran selanjutnya adalah untuk mengkombinasikan penanaman dan pengelolaan sumber daya hutan kota dengan strategi lain yang memperhitungkan karakteristik lingkungan perkotaan misalnya: struktur bangunan, desain jalan, lokasi sumber lokal; dll (Wissal Selmi, dkk, 2016).

Berdasarkan Peraturan Menteri Pekerjaan Umum Nomor : 05/Prt/M/2008 Tentang Pedoman Penyediaan dan Pemanfaatan Ruang Terbuka Hijau Di Kawasan Perkotaan disebutkan bahwa Ruang terbuka hijau adalah area memanjang atau jalur dan/atau mengelompok, yang penggunaannya lebih bersifat terbuka, tempat tumbuh tanaman, baik yang tumbuh secara alamiah maupun yang sengaja ditanam (Umum, 2008).
Ketersediaan Ruang Terbuka Hijau (RTH) minimal 30\% merupakan syarat utama dalam pembangunan berkelanjutan di Kota Cimahi. Kurangnya ketersediaan RTH dapat menyebabkan peningkatan konsentrasi karbondioksida $\mathrm{CO}_{2}$ (Nurani Ikhlas, Taufik Abdullah, \& Rachmat Boedisantoso, 2017). Dengan demikian, masyarakat dapat berperan untuk meningkatkan kualitas udara di permukiman dengan menyediakan ruang terbuka hijau sekitar 30\%. Sehingga tersedianya ruang terbuka hijau dapat memberikan keuntungan lingkungan yang signifikan bagi masyarakat.

Upaya ini dalam rangka rangka pengelolaan kualitas udara Permukiman. Kualitas udara yang baik di Permukiman diharapkan dapat meningkatkan tingkat kesehatan masyarakat sehingga dapat meningkatkan kesempatan bekerja lebih baik dan pada akhirnya dapat meningkatkan kesejahteraan masyarakat.

\section{KESIMPULAN}

Berdasarkan hasil penelitian, didapatkan bahwa parameter udara gas yang diuji yakni nitrogen dioksida $\left(\mathrm{NO}_{2}\right)$, sulfur dioksida $\left(\mathrm{SO}_{2}\right)$, karbon monoksida $(\mathrm{CO})$, oksidan $\left(\mathrm{O}_{3}\right)$, pada tiga lokasi permukiman di Kota Cimahi masih memenuhi baku mutu udara ambient berdasarkan PP No. 41/1999 tentang Pengendalian Pencemaran Udara. Sementara nilai partikulat untuk lokasi Permukiman di Kecamatan Cimahi Selatan dan Kecamatan Cimahi Utara melebihi baku mutu. Masyarakat dapat berperan untuk meningkatkan kualitas udara dengan menyediakan ruang terbuka hijau sehingga dapat memberikan keuntungan lingkungan bagi masyarakat.

\section{DAFTAR PUSTAKA}

Buddhi Pushpawela, Rohan Jayaratne, Lidia Morawska. (2018). The influence of wind speed on new particle formation events in an urban environment. Atmospheric Research, 37-41.

Cheuk Hei Marcus Tong, Steve Hung Lam Yim, Daniel Rothenberg, Chien Wang, Chuan-Yao Lin, Yongqin David Chen, Ngar Cheung Lau. (2018). Assessing the impacts of seasonal and vertical atmospheric conditions on air quality over the Pearl River Delta region. Atmospheric Environment, 69-78. 
Danting Zhao, Hong Chen, Xuedong Li, Xiaotong Ma. (2018). Air pollution and its influential factors in China's hot spots. Journal of Clenaer Production, 619=627.

Dayaratne, R. (2018). Toward sustainable development:Lessons. Frontiers of Architectura lResearch, 1-13.

Egide Kalisa, Sulaiman Fadlallah, Mabano Amani, Lamek Nahayo, Gabriel Habiyaremye. (2018). Temperature and air pollution relationship during heatwaves in Birmingham, UK. Sustainable Cities and Society, 111120.

Eleni Sinakou, Jelle Boeve-de Pauw, Maarten Goossens, Peter Van Petegem;. (2018). Academics in the field of Education for Sustainable Development: Their conceptions of sustainable development. Jurnal of Cleaner Production, 321-332.

Guicai Ning, Shigong Wang, Minjin Ma, Changjian Ni, Ziwei Shang, Jiaxin Wang, Jingxin Li. (2018). Characteristics of air pollution in different zones of Sichuan Basin, China. Science of The Total Environment, 975-984.

Guodong Du, Kong Joo Shin, Shunsuke Managi. (2018). Variability in impact of air pollution on subjective wellbeing. Atmospheric Environment, 166.

H. Puxbaum, K. Gabler, S. Smidt, F. Glattes. (1991). A one-year record of ozone profiles in an Alpine valley (Zillertal/Tyrol, Austria, 600-2000 m a.s.1.). Atmospheric Environment. Part A. General Topics, 1759-1765.

Hong Qiu, Ignatius Tak Sun Yu, Xiaorong Wang, Linwei Tian, Lap Ah Tse, Tze Wai Wong. (2013). Season and humidity dependence of the effects of air pollution on COPD hospitalizations in Hong Kong. Atmospheric Environment, 74-80.

Indonesia, R. (2011). Undang-Undang Nomor 1 Tahun 2011 Tentang Perumahan dan Kawasan Permukiman. Indonesia: Republik Indonesia.
Jing Huang, Xiaochuan Pan, Xinbiao Guo, Guoxing Li. (2018). Impacts of air pollution wave on years of life lost: A crucial way to communicate the health risks of air pollution to the public. Environment International, 42-49.

Lisha Tang, Matthias Ruth, Qingyun He, Sahar Mirzaee. (2017).

Comprehensive evaluation of trends in human settlements quality changes. Habitat International, 81-90.

Munfarida. (2016). EVALUASI KUALITAS UDARA STUDI KASUS 3 LOKASI PUSKESMAS DI KOTA CIMAHI PROVINSI JAWA BARAT. $A L-A R D$ $\therefore$ JURNAL TEKNIK LINGKUNGAN, 67-73.

Nurani Ikhlas, Taufik Abdullah, \& Rachmat Boedisantoso. (2017). Calculation Method of Green Open Space Based on Carbon Emission from Transportation Sector in Surabaya. IPTEK, The Journal for Technology and Science, 37-41.

Santoso, Jo, Budi P. Iskandar, dan Parwoto. (2002). Sistem Perumahan Sosial di Indonesia. Jakarta: Pusat Studi Perkotaan Universitas Indonusa dan IAP.

Sanyi Tang, Qinling Yan, Wei Shi, Xia Wang, Xiaodan Sun, Pengbo Yu, Jianhong Wu, Yanni Xiao. (2018). Measuring the impact of air pollution on respiratory infection risk in China. Environmental Pollution, 477-486.

Sinha, S. N. (2018). Air Pollution From Solid Fuels. Reference Module in Earth Systems and Environmental Sciences, 46-52.

Soedomo. (2001). Pencemaran Udara. Bandung: ITB.

Statistik, B. P. (2017). Cimahi Dalam Angka . Cimahi: Badan Pusat Statistik.

Umum, M. P. (2008). Peraturan Menteri Pekerjaan Umum Nomor 05/Prt/M/2008 tentang Pedoman Penyediaan dan Pemanfaatan Ruang Terbuka Hijau di Kawasan Perkotaan. Jakarta: Menteri Pekerjaan Umum. 
Wissal Selmi, Christiane Weber, Emmanuel Rivière, Nadège Blond, Lotfi Mehdi, David Nowak. (2016). Air pollution removal by trees in public green spaces in Strasbourg city, France. Urban Forestry \& Urban Greening, 192-201. 